\title{
Epicardial Neoplasm
}

National Cancer Institute

\section{Source}

National Cancer Institute. Epicardial Neoplasm. NCI Thesaurus. Code C5347.

A benign or malignant neoplasm that affects the inner layer of the pericardium. 